Огляди літератури, оригінальні дослідження, погляд на проблему, випадок з практики, короткі повідомлення УДК 612.015.1:616.24-02:616.137-005.1/.4-007.271]-092.9

DOI 10.11603/1811-2471.2020.v.i3.11596

\title{
ОСОБЛИВОСТІ ПОРУШЕНЬ ПОКАЗНИКІВ ЕНЗИМНОї ЛАНКИ АНТИОКСИДАНТНОЇ СИСТЕМИ В ЛЕГЕНЯХ ЩУРІВ ПІСЛЯ ГОСТРОЇ КРОВОВТРАТИ, УСКЛАДНЕНОї ІШЕМІЄЮ-РЕПЕРФУЗІЄЮ КІНЦІВКИ
}

\author{
๑О. В. Стахів, А. А. Гудима
}

Тернопільський національний медичний університет імені І. Я. Горбачевського МОз України

РЕЗЮМЕ. Одним із ключових патогенних механізмів масивної зовнішньої крововтрати з кінцівок $\epsilon$ активація процесів ліпідної пероксидації, зумовлена, з одного боку, розвитком гіпоксії, з іншого - виснаженням антиоксидантного захисту. Застосування за цих умов кровоспинного джгута супроводжується ішемічно-реперфузійним пошкодженням кінцівки, що ускладнює перебіг гострої крововтрати. На сьогодні недостатньо даних про особливості порушень антиоксидантного захисту в легенях, які належать до ключових органів-мішеней гострої крововтрати та ішемічно-реперфузійного синдрому.

Мета - з' ясувати особливості порушень показників ензимної ланки антиоксидантної системи в легенях щурів після гострої крововтрати, ускладненої ішемією-реперфузією кінцівки.

Матеріал і методи. Дослідження проведено на 156 білих нелінійних щурах-самцях масою $200-220$ г. Усі експерименти виконані під тіопентал-натрієвим наркозом. У тварин моделювали ішемію-реперфузію кінцівки, гостру крововтрату та поєднували ці ушкодження. Через 1 і 2 години, а також через 1, 7 i 14 діб у гомогенатах легень піддослідних тварин визначали активність супероксиддисмутази і каталази.

Результати. За умов моделювання лише ішемії-реперфузії кінцівки активність СОД та каталази у гомогенаті легень зростала з максимумом через 2 год експерименту та нормалізацією показників до 14 доби. За умов гострої крововтрати показники зростали у всі терміни спостереження з максимумом через 1 добу експерименту. Додаткова ішемія-реперфузія кінцівки на тлі гострої крововтрати у легенях сприяє виснаженню СОД і каталази, активність яких через 1, 7 і 14 діб стає істотно меншою, порівняно з тваринами дослідної групи, в якій моделювали лише крововтрату.

Висновки. Ускладнення гострої крововтрати ішемією-реперфузією кінцівки сприяє більшому виснаженню в легенях ферментативної ланки антиоксидантного захисту через 1, 7 і 14 діб експерименту, що виявляють за істотним зниженням активності СОД і каталази в легенях порівняно з тваринами, яким моделювали лише гостру крововтрату.

КлючОВІ СлОВА: гостра крововтрата; ішемія-реперфузія кінцівки; супероксиддисмутаза; каталаза; легені.

Вступ. На сьогодні доведено, що одним із ключових патогенних механізмів гострої крововтрати $€$ активація процесів ліпідної пероксидації, зумовлена, з одного боку, розвитком гіпоксії, з іншого - виснаженням антиоксидантного захисту [1]. За умов гіпоксії виникають передумови для утворення активних форм кисню, які, завдяки переокисненню білків і ліпідів клітинних мембран, сприяють їх деструкції з посиленням ендотоксикозу та розвитком поліорганної недостатності $[2,3]$.

Актуальність проблеми гострої масивної крововтрати з кінцівок зумовлена тим, що остання $\epsilon$ однією з провідних причин смерті за умов бойової травми [4]. Своєчасне застосування кровоспинного джгута, який під вогнем противника накладається максимально проксимально з граничним терміном до двох годин, істотно знижує летальність поранених. Разом з тим, у ряді експериментальних досліджень показано, що повне знекровлення кінцівки протягом двох годин на тлі масивної зовнішньої крововтрати у реперфузійному періоді супроводжується посиленням процесів ліпідної пероксидації у внутрішніх органах, яке не знижується протягом 14 діб експерименту $[5,6]$.
За цих умов недостатньо даних про особливості порушень антиоксидантного захисту в легенях, які належать до ключових органів-мішеней гострої крововтрати та ішемічно-реперфузійного синдрому [7]. Недослідженою залишається ефективність карбацетаму, одним з механізмів дії якого $€$ антиоксидантний вплив [5].

Мета - з'ясувати особливості порушень показників ензимної ланки антиоксидантної системи в легенях щурів після гострої крововтрати, ускладненої ішемією-реперфузією кінцівки.

Матеріал і методи дослідження. Дослідження проведено на 156 білих нелінійних щурах-самцях віком 6-8 місяців масою 200-220 г, яких утримували в одному приміщенні при постійній температурі $18-22{ }^{\circ} \mathrm{C}$ на стандартному режимі віварію. Усі експерименти виконано з дотриманням норм Конвенції Ради Європи про захист хребетних тварин, що використовуються для досліджень та інших наукових цілей (Страсбург, 1986), ухвали Першого національного конгресу з біоетики (Київ, 2001) і наказу МОЗ України № 690 від 23.09.2009 р. Комісія з питань біоетики Тернопільського національного медичного університету імені І. Я. Горба- 
Огляди літератури, оригінальні дослідження, погляд на проблему, випадок з практики, короткі повідомлення чевського МОЗ України порушень морально-етичних норм при проведенні науково-дослідної роботи не виявила.

Усі експерименти виконані під тіопентал-натрієвим наркозом (40 мг/кг). Усіх тварин поділили на чотири групи: контрольну (6 щурів) та три дослідних. У дослідній групі 1 (50 щурів) тваринам моделювали ішемію-реперфузію кінцівки шляхом накладання проксимально на ліву лапку смужки еластичного джгута «SWAT-T» (США) шириною 10 мм на 120 хв [5]. У дослідній групі 2 (50 щурів) моделювали гостру крововтрату (20 \% від об' єму циркулюючої крові) шляхом пересікання стегнової вени. У третій дослідній групі ці ушкодження поєднували (50 щурів). У контрольній групі тварин тільки вводили в наркоз і в подальшому брали для досліджень через 3 год.

Через 1 і 2 години, а також через 1, 7 i 14 діб дослідних тварин 1, 2 і 3 груп, а також через 7 i 14 діб дослідних тварин 4 групи виводили з експерименту методом тотального кровопускання 3 серця. Для досліджень брали легені, в гомогенаті яких визначали активність супероксиддисмутази (СОД, КФ 1.1.15.1.) [8] і каталази (КФ 1.11.1.6) [9].

Оцінку вірогідності відмінностей між експериментальними групами проводили з використанням непараметричного критерію МаннаУїтні.

Результати й обговорення. Дослідження показали, що у тварин, яким моделювали лише ішемію-реперфузію кінцівки (табл. 1), активність СОД легень, порівняно з контролем, через 1 год зросла на $36,1 \%$, через 2 год - на 89,2\%, через 1 добу - на 63,7 \% і через 7 діб - на 27,4 \% (р<0,05). Варто відмітити, що через 14 діб реперфузійного періоду активність СОД у гомогенаті легень статистично вірогідно відрізнялася від контрольної групи. В динамці максимальні порушення спостерігали через 2 год реперфузійного періоду. В цей термін показник ставав вищим на 39,0 \% (p<0,05) стосовно 1 години експерименту. Через 1 добу показник на 20,3 \% перевищував дані через 1 годину, проте був на 13,5 \% нижчим стосовно 2 години спостереження (рс0,05). Через 7 діб експерименту активність СОД гомогенату легень була нижчою на 22,2 \% порівняно з рівнем 1 доби (p<0,5), на 32,7 \% - стосовно 2 години експерименту $(p<0,05)$ та статистично вірогідно не відрізнялася порівняно з 1 годиною експерименту (р>0,05). Через 14 діб експерименту активність СОД гомогенату легень була вірогідно нижчою відносно даних 1 і 2 годин та 1 і 7 діб експерименту - відповідно на 22,8, 44,5 35,8 і 17,5 \% ( $p<0,05)$.

Таблиця 1. Зміни активності СОД у гомогенаті легень щурів після гострої крововтрати, ускладненої ішемієюреперфузією кінцівки $\left(\mathrm{Me}\left(\mathrm{Q}_{25} ; \mathrm{Q}_{75}\right)\right)$

\begin{tabular}{|c|c|c|c|c|c|}
\hline \multirow{2}{*}{ Дослідна група } & \multicolumn{5}{|c|}{ Термін реперфузійного періоду } \\
\hline & 1 год & 2 год & 1 доба & 7 доба & 14 доба \\
\hline \multicolumn{6}{|c|}{ Контроль = 20,80 $(19,43 ; 24,13)(n=6)$} \\
\hline $\begin{array}{l}\text { Група } 1 \\
\text { Ішемія-реперфузія }\end{array}$ & $\begin{array}{c}28,30^{*} \\
(24,80 ; 29,50) \\
(n=10)\end{array}$ & $\begin{array}{c}39,35^{* 1 r} \\
(38,56 ; 40,23) \\
(n=10)\end{array}$ & $\begin{array}{c}34,05^{* 11,2 r} \\
(31,90 ; 36,08) \\
(n=10)\end{array}$ & $\begin{array}{c}26,50^{* 2 r, 1 д} \\
(25,63 ; 28,10) \\
(n=10)\end{array}$ & $\begin{array}{c}21,85^{1,2 r, 11,7 д} \\
(19,75 ; 23,25) \\
(n=10)\end{array}$ \\
\hline$P_{1-2}$ & $>0,05$ & $>0,05$ & $<0,05$ & $<0,05$ & $<0,05$ \\
\hline $\begin{array}{l}\text { Група } 2 \\
\text { Крововтрата }\end{array}$ & $\begin{array}{c}29,75^{*} \\
(29,00 ; 31,38) \\
(n=10)\end{array}$ & $\begin{array}{c}37,85^{* 1 \Gamma} \\
(37,28 ; 45,03) \\
(n=10)\end{array}$ & $\begin{array}{c}47,20 * 11,2 r \\
(43,20 ; 50,80) \\
(n=9)\end{array}$ & $\begin{array}{c}36,15^{* 11,1 д} \\
(31,75 ; 37,80) \\
(n=8)\end{array}$ & $\begin{array}{c}44,45^{* 1 г, 2 r, 7 д} \\
(39,38 ; 49,13) \\
(n=8)\end{array}$ \\
\hline$P_{2-3}$ & $<0,05$ & $>0,05$ & $<0,05$ & $<0,05$ & $<0,05$ \\
\hline $\begin{array}{l}\text { Група } 3 \\
\text { Ішемія-реперфузія+ } \\
\text { крововтрата }\end{array}$ & $\begin{array}{c}35,85^{*} \\
(32,48 ; 37,88) \\
(n=10)\end{array}$ & $\begin{array}{c}40,00 *(34,33 ; \\
44,03) \\
(n=10)\end{array}$ & $\begin{array}{c}28,15^{* 11,2 r} \\
(24,28 ; 31,68) \\
(n=8)\end{array}$ & $\begin{array}{c}20,80^{11,2 r, 1 \mathrm{~A}} \\
(17,95 ; 22,25) \\
(n=8)\end{array}$ & $\begin{array}{c}13,40 * 1 г, 2 r, 11,7 д \\
(13,05 ; 15,55) \\
(n=8)\end{array}$ \\
\hline$P_{1-3}$ & $<0,05$ & $>0,05$ & $<0,05$ & $<0,05$ & $<0,05$ \\
\hline
\end{tabular}

Примітки. Тут і в табл. 2:

1. * - відмінності стосовно контрольної групи статистично вірогідні $(p<0,05)$;

2. $\mathrm{p}_{1-2}-$ вірогідність відмінностей між дослідними групами 1 і 2;

3. $\mathrm{p}_{1-3}$ - вірогідність відмінностей між дослідними групами 1 i 3;

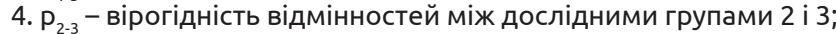

5. 1г,2г,1,7д - відмінності стосовно відповідно 1 і 2 год, а також 1 і 7 діб експерименту статистично вірогідні $(p<0,05)$.

У щурів, яким моделювали гостру крововтрату, активність СОД у гомогенаті легень порівняно 3 контролем зростала більш виражено: через 1 годину на 43,0 \%, через 2 години - на 82,0\%, через 1 добу - в 2,3 раза, через 7 діб - на 73,6 \%, че- рез 14 діб - в 2,1 раза ( $<<0,05)$. У динаміці максимальні порушення показника виникали через 1 добу експерименту. Через 2 години, порівняно 3 даними через 1 годину, показник ставав вищий на 27,2 \% (p<0,05). Через 1 добу експерименту показ- 
Огляди літератури, оригінальні дослідження, погляд на проблему, випадок з практики, короткі повідомлення ник перевищував дані через 1 годину спостереження на 58,7 \%, та дані через 2 години спостереження - на 24,7 \% (р<0,05). Через 7 діб експерименту активність СОД гомогенату легень ставала меншою, порівняно з 1 добою, на 23,5\% ( $<<0,05)$, перевищувала на 21,3 \% дані на 1 годину $(p<0,05)$ та статистично вірогідно не відрізнялася порівняно з 2 годиною спостереження ( $>0,05)$. Через 14 діб експерименту величина досліджуваного показника статистично вірогідно не відрізнялася від показника через 1 добу спостереження $(p>0,05)$ та вірогідно перевищувала дані через 1 годину, 2 години та 7 діб (відповідно на 49,4, 17,4 та 23, 1 \%, $\mathrm{p}<0,05)$.

У щурів, яким моделювали гостру крововтрату, ускладнену ішемією-реперфузією кінцівки, активність СОДу гомогенаті легень стосовно контролю вірогідно зростала через 1 годину на 72,4\%, через 2 години - на 92,3 \%, через 1 добу - на 35,3\%. Через 7 діб даний показник вірогідно не відрізнявся від даних контрольної групи, а через 14 діб - був нижчим на 35,6 \% ( $<<0,05)$.

У динаміці експерименту максимальні порушення активності СОД гомогенату легень спостерігали через 2 години експерименту. В цей термін даний показник статистично вірогідно не відрізнявся стосовно даних 1 години експерименту $(p<0,05)$. Через 1 добу експерименту показник був вірогідно нижчим стосовно даних 1 години спостереження (на 21,5 \%, p<0,05) та даних 2 години спостереження (на 29,6 \%, p<0,05). Через 7 діб експерименту активність СОД гомогенату легень ставала на 26,1 \% меншою, порівняно з даними 1 доби $(p<0,05)$, на 48,0 \% порівняно 3 даними 2 години $(p<0,05)$ та на $42,0 \%$ стосовно 1 години спостереження ( $<<0,05)$. Через 14 діб експерименту даний показник ставав статистично вірогідно меншим,

порівняно з даними 1 і 2 годин, 1 та 7 діб експерименту (відповідно у 2,7 раза, у 3,0 рази, у 2,1 раза та на 35,6\%).

Порівняння дослідних груп між собою показало, що за умов гострої крововтрати активність СОД гомогенату легень ставала істотно більшою, порівняно з тваринами, яким моделювали ішемію-реперфузію кінцівки, через 1, 7 і 14 діб експерименту (відповідно на 38,6, 36,4 і та у 2,04 раза, $\left.\mathrm{p}_{1-2}<0,05\right)$. Після моделювання гострої крововтрати, ускладненої ішемією-реперфузією кінцівки, показник у всі терміни спостереження був істотно більшим, ніж після ішемії-реперфузії кінцівки $\left(p_{1-3}<0,05\right)$ за винятком 2 години спостереження $\left(p_{1-3}>0,05\right)$. Порівняно з групою, в якій моделювали лише гостру крововтрату, показник через 1 добу був на $20,5 \%$ більшим $\left(p_{2-3}<0,05\right)$. Водночас, через 1, 7 і 14 діб показник після гострої крововтрати, ускладненої ішемією-реперфузією кінцівки, ставав статистично вірогідно меншим, ніж у групі, в якій моделювали лише гостру крововтрату (відповідно на 40,4, 42,5 і 20,4 \%, $\left.\mathrm{p}_{2-3}<0,05\right)$.

Натомість активність каталази гомогенату легень тварин (табл. 2), яким моделювали ішеміюреперфузію кінцівки, через 1 годину реперфузійного періоду порівняно з контролем зростала на $10,0 \%$, проте отриманий результат виявився статистично не вірогідними ( $>>0,05)$. Через 2 години спостереження показник перевищував контроль на 53,3 \%, через 1 добу - на 20,2 \% (p<0,05). Через 7 діб показник знижувався, досягав рівня контролю й на такому ж рівні залишався до 14 доби (p>0,05). У динаміці максимальні порушення досліджуваного показника відмічали через 2 години після моделювання ішемії-реперфузії кінцівки. В цей термін спостереження показник на 39,3 \% був вищий, порівняно з даними на 1 годину експери-

Таблиця 2. Порушення активності каталази в гомогенаті легень у щурів після гострої крововтрати, ускладненої ішемією-реперфузією кінцівки $\left(\mathrm{Me}\left(\mathrm{Q}_{25} ; \mathrm{Q}_{75}\right)\right)$

\begin{tabular}{|c|c|c|c|c|c|}
\hline \multirow{2}{*}{ Дослідна група } & \multicolumn{5}{|c|}{ Термін реперфузійного періоду } \\
\hline & 1 год & 2 год & 1 доба & 7 доба & 14 доба \\
\hline \multicolumn{6}{|c|}{ Контроль $=14,45(13,35 ; 14,88)(n=6)$} \\
\hline $\begin{array}{l}\text { Група } 1 \\
\text { Ішемія-реперфузія }\end{array}$ & $\begin{array}{c}15,90 \\
(13,93 ; 16,88) \\
(n=10)\end{array}$ & $\begin{array}{c}22,15^{* 1 \Gamma} \\
(19,00 ; 24,90) \\
(n=10)\end{array}$ & $\begin{array}{c}17,37^{* 2 r} \\
(15,26 ; 18,39) \\
(n=10)\end{array}$ & $\begin{array}{c}15,50^{2 r} \\
(14,23 ; 16,63) \\
(n=10)\end{array}$ & $\begin{array}{c}13,00^{1 г, 2 г, 1 д, 7 д} \\
(12,35 ; 13,50) \\
(n=10)\end{array}$ \\
\hline $\mathrm{P}_{1-2}$ & $>0,05$ & $>0,05$ & $<0,05$ & $<0,05$ & $<0,05$ \\
\hline $\begin{array}{l}\text { Група } 2 \\
\text { Крововтрата }\end{array}$ & $\begin{array}{c}19,44^{*} \\
(16,94 ; 20,35) \\
(n=10)\end{array}$ & $\begin{array}{c}25,60 * 15 \\
(23,18 ; 26,45) \\
(n=10)\end{array}$ & $\begin{array}{c}31,20 * 11,2 r \\
(29,20 ; 32,50) \\
(n=9)\end{array}$ & $\begin{array}{c}24,30 * 11,1 д \\
(22,60 ; 26,45) \\
(n=8)\end{array}$ & $\begin{array}{c}28,95^{* 11,7 \text { म }} \\
(26,78 ; 29,15) \\
(n=8)\end{array}$ \\
\hline$P_{2-3}$ & $>0,05$ & $>0,05$ & $<0,05$ & $<0,05$ & $<0,05$ \\
\hline $\begin{array}{l}\text { Група } 3 \\
\text { Ішемія-реперфузія+ } \\
\text { крововтрата }\end{array}$ & $\begin{array}{c}21,20^{*} \\
(19,15 ; 22,80) \\
(n=10)\end{array}$ & $\begin{array}{c}25,05^{* 15} \\
(23,80 ; 25,60) \\
(n=10)\end{array}$ & $\begin{array}{c}16,52^{1,2 r} \\
(15,66 ; 17,74) \\
(n=8)\end{array}$ & $\begin{array}{c}14,30^{1 r, 2 r} \\
(12,90 ; 14,95) \\
(n=8)\end{array}$ & $\begin{array}{c}8,52 * 11,2 г, 1 д, 7 д \\
(7,77 ; 8,93) \\
(n=8)\end{array}$ \\
\hline$P_{1-3}$ & $>0,05$ & $>0,05$ & $>0,05$ & $>0,05$ & $<0,05$ \\
\hline
\end{tabular}


Огляди літератури, оригінальні дослідження, погляд на проблему, випадок з практики, короткі повідомлення менту $(p<0,05)$. Через 1 добу експерименту показник статистично вірогідно не відрізнявся від даних на 1 годину, але на $21,6 \%$ був нижчим порівняно 3 даними через 2 години експерименту $(p<0,05)$. Через 7 діб активність каталази гомогенату легень ставала нижчою порівняно з 2 годиною на 30,0\% $(p<0,05)$ та статистично вірогідно не відрізнялася стосовно 1 год та 1 доби експерименту ( $>>0,05)$. Через 14 діб експерименту активність каталази знижувалася й була статистично вірогідно нижчою стосовно 1 і 2 годин та 1 і 7 діб експерименту (відповідно на $18,2,41,3,25,2$ та $16,1 \%$, p<0,05).

У щурів, яким моделювали крововтрату, активність каталази у гомогенаті легень стосовно контролю статистично вірогідно зростала: через 1 годину на $34,5 \%$, через 2 години - на $77,2 \%$, через 1 добу - в 2,2 раза, через 7 діб - на 68,2 \%, через 14 діб - у 2,0 раза $(p<0,05)$. У динамці експерименту встановлено, що за умов гострої крововтрати максимальні порушення виникали через 1 добу експерименту. Через 2 години показник був на 31,7 \% вищий стосовно даних на 1 годину $(p<0,05)$. Через 1 добу показник на 60,5 \% перевищував дані на 1 годину спостереження $(p<0,05)$ та на $21,9 \%$ дані на 2 годину спостереження $(p<0,05)$. Через 7 діб експерименту активність каталази гомогенату легень ставала на 22,1 \% меншою, порівняно $з 1$ добою $(p<0,05)$, при цьому на 25,0 \% перевищувала дані 1 години $(p<0,05)$ та статистично вірогідно не відрізнялася порівняно з 2 годиною спостереження ( $>>0,05)$. Через 14 діб експерименту активність каталази гомогенату легень істотно не відрізнялася порівняно з 2 годиною та 1 добою спостереження $(p>0,05)$ та статистично вірогідно перевищувала дані 1 години та 7 доби спостереження (відповідно на 48,9, 19,1 \%, p<0,05).

У щурів, яким моделювали крововтрату, ускладнену ішемією-реперфузією кінцівки, активність каталази у гомогенаті легень стосовно контролю зростала: через 1 годину на 46,7 \%, через 2 години - на 73,4 \%, що виявилося статистично вірогідним ( $<<0,05)$. Через 1 та 7 діб експерименту показник знижувався і статистично вірогідно не відрізнявся від даних контрольної групи $(p<0,05)$, а через 14 діб ставав статистично вірогідно меншим - на 41,0 \% ( $<<0,05)$. У динаміці експерименту максимальні порушення відмічали через 2 години спостереження. В цей термін показник був вищим, порівняно з 1 годиною спостереження, на 18,2 \% $(p<0,05)$. Через 1 добу експерименту показник вірогідно був нижчимстосовно 1 години спостереження (на $22,1 \%, p<0,05)$ та даних 2 години спостереження (на $34,1 \%, 0<0,05$ ). Через 7 діб експерименту активність каталази гомогенату легень статистично вірогідно не відрізнялася від показника 1 доби ( $p>0,05)$, була на 42,9% меншою, порівняно з 2 годиною $(p<0,05)$ та на $32,5 \%$ - порівняно з 1 годиною спостереження $(p<0,05)$. Через 14 діб експерименту показник був статистично вірогідно нижчим, порівняно з 1 і 2 годинами та 1 і 7 добами (відповідно у 2,5 і 2,9 раза, на 48,4 та 40,4 \%, p<0,05).

Порівняння дослідних груп між собою показало, що активність каталази у групі тварин з гострою крововтратою, порівняно з тваринами, в яких моделювали лише ішемію-реперфузію кінцівки, через 1, 7 і 14 діб була статистично вірогідно більшою (відповідно на 79,6, 56,8 та у 2,22 раза, $\left.\mathrm{P}_{1-2}<0,05\right)$. За умов гострої крововтрати, ускладненої ішемією-реперфузією кінцівки, порівняно $з$ тваринами, в яких моделювали лише ішемію-реперфузію кінцівки, показник у всі терміни спостереження істотно не відрізнявся $\left(p_{1-3}>0,05\right)$, за винятком 14 доби. В цей термін показник ставав істотно меншим (на 40,2 \%, $\left.\mathrm{p}_{1-3}<0,05\right)$. Порівняно 3 групою, в якій моделювали лише гостру крововтрату, активність каталази гомогенату легень через 1, 7 і 14 діб була статистично вірогідно меншою (відповідно на 47,0, 41,2 та 70,6\%, $\mathrm{P}_{2-3}<0,05$ ).

Отримані результати свідчать про те, що за умов моделювання лише ішемії-реперфузії кінцівки активність СОД та каталази у гомогенаті легень зростала, з максимумом через 2 години експерименту та нормалізацією величин показників до 14 доби. Як свідчать дані [10], подібне зростання має компенсаторний характер у відповідь на прооксидантні ендотоксини, які надходять $з$ кінцівки після ії̈ реперфузії $[11,12]$. За умов гострої крововтрати показники зростали у всі терміни спостереження з максимумом через 1 добу експерименту. Можна припустити, що у відповідь на гіпоксію, зумовлену гострою крововтратою, в легенях виникають передумови для генерації активних форм кисню, які активують ферменти антиоксидантної системи, здатні їх нейтралізувати: СОД і каталазу. Враховуючи, що в легенях за цих умов активність досліджуваних ферментів у всі терміни підвищена, цілком ймовірно, що така реакція знаходиться в межах гомеостатичного регулювання і свідчить про достатньо високий рівень резервних можливостей ферментативної ланки антиоксидантного захисту в легенях.

Водночас додаткова ішемія-реперфузія кінцівки на тлі гострої крововтрати у легенях сприяє виснаженню СОД і каталази, активність яких через 1, 7 і 14 діб стає істотно меншою, порівняно 3 тваринами дослідної групи, в якій моделювали лише крововтрату. Цей факт свідчить про те, що за умов гострої крововтрати, ускладненої ішемієюреперфузією кінцівки, в легенях зростає вміст активних форм кисню, що, ймовірно $є$ наслідком нашарування гіпоксійних порушень, зумовлених гострю крововтратою та наявністю прооксидант- 
Огляди літератури, оригінальні дослідження, погляд на проблему, випадок з практики, короткі повідомлення них ендотоксинів, які надходять у мале коло кровообігу з ішемізованої кінцівки після її реперфузії, на що вказують дані окремих авторів $[11,12]$. Враховуючи, що виснаження антиоксидантного захисту й накопичення продуктів ліпідної пероксидації ініціюють системну відповідь організму на запалення [13], можна припустити, що ускладнення гострої крововтрати ішемією-реперфузією кінцівки $є$ пусковим чинником розвитку гострого ураження легень.

Отже, ускладнення гострої крововтрати ішемією-реперфузією кінцівки сприяє посиленому надходженню активних форм кисню в легені і зумовлює декомпенсацію ферментативної ланки антиоксидантного захисту першої лінії, спрямованої на їх нейтралізацію. Отримані результати слід брати до уваги за умов лікування поранених 3 гострою крововтратою, в яких протягом двох годин була ішемізована кінцівка внаслідок застосування кровоспинного джгута.

\section{ЛІТЕРАТУРА}

1. Зыблев С. Л. Состояние метаболизма при экспериментальной острой массивной кровопотере в зависимости от проводимой терапии / С. Л. Зыблев, 3. А. Дундаров // Новости хирургии. - 2013. - Т. 21, № 5. - С. 3-10.

2. Вплив ішемічно-реперфузійного синдрому на активацію системи перекисного окиснення ліпідів у тканині печінки / В. О. Крилюк, І. В. Кузьмінський, В. К. Гродецький [та ін.] // Клінічна та експерим. патологія. - 2018. - № 4 (66). - С. 53-59.

3. Цимбалюк Г. Ю. Стан системи пероксидного окиснення ліпідів у тканині нирки на фоні травми органів черевної порожнини та реперфузії кінцівок / Г. Ю. Цимбалюк // Екстрена медицина: від науки до практики. 2018. - № 3 (29). - C. 23-32.

4. Point of injury tourniquet application during Operation Protective Edge-What do we learn? / A. Shlaifer, A. Yitzhak, E. N. Baruch [et al.] // J. Trauma Acute Care Surg. - 2017. - Vol. 83, Issue 2. - P. 278-283.

5. Шацький В. В. Динаміка антиоксидантно-прооксидантного балансу кіркового і мозкового шарів нирки після гострої крововтрати, ускладненої ішемією-реперфузією кінцівки, та його корекція карбацетамом / В. В. Шацький, А. А. Гудима, Л. Я. Федонюк // Здобутки клініч. і експерим. медицини. - 2019. - № 4. - С. 144-153.

6. Volotovska N. V. Changes in the glutathione system's activity of internal organs in the first hours of experimental limb ischemia-reperfusion syndrome, combined with blood loss and mechanical injury / N. V. Volotovska, T. C. Nhokwara, I. V. Zhulkevych // Здобутки клініч. і експерим. медицини. - 2019. - № 1. - С. 23-27.

Висновки. 1. За умов моделювання лише ішемії-реперфузії кінцівки активність СОД та каталази у гомогенаті легень зростала з максимумом через 2 години експерименту та нормалізацією величин показників до 14 доби.

2. За умов гострої крововтрати показники зростали у всі терміни спостереження з максимумом через 1 добу експерименту. Ускладнення гострої крововтрати ішемією-реперфузією кінцівки сприяє виснаженню СОД і каталази, активність яких через 1, 7 і 14 діб стає істотно меншою, порівняно з тваринами дослідної групи, в якій моделювали лише крововтрату, що свідчить про більше зростання за цих умов у легенях активних форм кисню та виснаження антиоксидантного захисту.

Перспективи подальших досліджень. У перспективі доцільно провести скринінг антиоксидантів для корекції виявлених порушень, зумовлених гострою крововтратою та ішемією-реперфузією кінцівки.

7. Особливості антоксидантної системи захисту у динаміці розвитку гострого респіраторного дистрес-синдрому та при різних методах корекції у щурів / М. I. Марущак, С. О. Савчук, У. П. Гевко, О. В. Олійник // Scientific Journal «ScienceRise: Medical Science». - 2017. - № 6 (14). C. 18-23.

8. Чевари С. Роль супероксидредуктазы в окислительных процессах клетки и метод определения ее в биологическом материале / С. Чевари, И. Чаба, Й. Секей // Лабораторное дело. - 1985. - № 11. - С. 678-681.

9. Метод определения активности каталазы / М. А. Королюк, А. И. Иванова, И. Г. Майорова, В. Е. Токарев // Лабораторное дело. - 1988. - № 1. - С. 16-19.

10. Максимів Р. В. Динаміка балансу антиоксидантно-прооксидантних механізмів у внутрішніх органах під впливом артеріального джгута і реперфузії кінцівки / Р. В. Максимів, А. А. Гудима, В. М. Сидоренко // Шпитальна хірургія. Журнал імені Л. Я. Ковальчука. -2017. - № 1.C. 37-44.

11. Comparison of changes in markers of muscle damage induced by eccentric exercise and ischemia/reperfusion / Q. S. Su, J. G. Zhang, R. Dong [et al.] // Scand. J. Med. Sci. Sports. - 2010. - Vol. 20, No. 5. - P. 748-756.

12. Concentration decrease of nitric oxide in the postischemic muscle is not only caused by the generation of O2- / F. Stoffels, F. Lohöfener, M. Beisenhirtz [et al.] // Microsurgery. - 2007. - Vol. 27, No. 6. - P. 565-568.

13. Гудима А. А. Антиоксидантно-прооксидантний та цитокіновий баланс у пізній період комбінованої травми в експерименті / А. А. Гудима, Т. В. Кащак, К. В. Шепітько // Світ медицини та біології. - 2019. - № 1 (67). - С. 42-47. 
Огляди літератури, оригінальні дослідження, погляд на проблему, випадок з практики, короткі повідомлення REFERENCES

1. Zyblev, S.L., \& Dundarov, Z.A. (2013). Sostoyaniye metabolizma pri eksperimentalnoy ostroy massivnoy krovopotere $v$ zavisimosti ot provodimoy terapii [The state of metabolism in experimental acute massive blood loss, depending on the conducted therapy]. Novosti khirurgii Surgery News, 21, 5, 3-10 [in Russian].

2. Krylyuk, V.O., Kuzminskyi, I.V., Grodetskyi, V.K., Foundiur, V.D., Yakobchuk, S.O., Kolotylo, O.B., \& Khomko, O.Y. (2018). Vplyv ishemichno-reperfuziinoho syndromu na aktyvatsiiu systemy perekysnoho okysnennia lipidiv u tkanyni pechinky [Influence of ischemical-reperferual syndrome on activation of the lipid peroxidation system in the liver tissues in experiment]. Klinichna ta eksperym. patolohiia-Clinical and Experiment. Pathology, 4 (66), 53-59 [in Ukrainian].

3. Tsymbalyuk, H.Yu. (2018). Stan systemy peroksydnoho okysnennia lipidiv u tkanyni nyrky na foni travmy orhaniv cherevnoi porozhnyny ta reperfuzii kintsivok [The state of the system of peroxide oxidation of lipids in kidney tissue against the background of trauma of the abdominal organs and reperfusion of the extremities]. Ekstrena medytsyna: vid nauky do praktyky - Emergency Medicine: From Science to Practice, 3 (29), 23-32 [in Ukrainian].

4. Shlaifer, A., Yitzhak, A., Baruch, E.N., Shina, A., Satanovsky, A., Shovali, A., ..., \& Glassberg, E. (2017). Point of injury tourniquet application during Operation Protective Edge-What do we learn? J. Trauma Acute Care Surg., 83, 2, 278-283.

5. Shatsky, V.V., Gudyma, A.A., \& Fedoniuk, L.Y. (2019). Dynamika antyoksydantno-prooksydantnoho balansu kirkovoho i mozkovoho shariv nyrky pislia hostroi krovovtraty, uskladnenoi ishemiieiu-reperfuziieiu kintsivky, ta yoho korektsiia karbatsetamom [Dynamics of antioxidant-prooxidant balance of renal cortex and medulla after acute blood loss complicated by ischemia-reperfusion of the extremity, and its correction with carbacetam]. Zdobutky klinich. $i$ eksperym. medytsyny - Achievements of Clinical and Experiment. Medicine, 4, 144-153 [in Ukrainian].

6. Volotovska, N.V., Nhokwara, T.C., \& Zhulkevych, I.V. (2019). Changes in the glutathione systems activity of internal organs in the first hours of experimental limb ischemia-reperfusion syndrome, combined with blood loss and mechanical injury. Zdobutky klinich. i eksperym. medytsyny - Achievements of Clinical and Experiment. Medicine, 1, 23-27.
7. Marushchak, M.I., Savchuk, S.O., Hevko, U.P., \& Oliynyk, O.V. (2017). Osoblyvosti antoksydantnoi systemy zakhystu u dynamitsi rozvytku hostroho respiratornoho dystres-syndromu ta pry riznykh metodakh korektsii u shchuriv [Peculiarities of antioxidant protection system in the dynamics of acute respiratory distress syndrome development and at different methods of its correction in rats]. Scientific Journal "ScienceRise: Medical Science", 6 (14), 1823 [in Ukrainian].

8. Chevari, S., Chaba, I., \& Sekey, Y. (1985). Rol superoksidreduktazy $v$ okislitelnykh protsessakh kletki i metod opredeleniya yeye $v$ biologicheskom materiale [The role of superoxide reductase in the oxidative processes of the cell and the method for its determination in biological material]. Laboratornoye delo - Laboratory Work, 11, 678-681 [in Russian].

9. Korolyuk, M.A., Ivanova, A.I., Mayorova, I.G., \& Tokarev, V.Ye. (1988). Metod opredeleniya aktivnosti katalazy [Method for determining the activity of catalase]. Laboratornoye delo - Laboratory Work, 1, 16-19 [in Russian].

10. Maksymiv, R.V., Hudyma, A.A., \& Sydorenko, V.M. (2017). Dynamika balansu antyoksydantno-prooksydantnykh mekhanizmiv u vnutrishnikh orhanakh pid vplyvom arterialnoho dzhhuta i reperfuzii kintsivky [Dynamic of balance of antioxidant-prooxidant mechanism in internal organs Under the influence of blood harnesses and limb reperfusion]. Shpytalna khirurhiia. Zhurnal imeni L.Ya. Kovalchuka - Hospital Surgery. Journal Named by L.Ya. Kovalchuk, 1, 37-44 [in Ukrainian].

11. Su, Q.S., Zhang, J.G., Dong, R., Hua, B., \& Sun, J.Z. (2010). Comparison of changes in markers of muscle damage induced by eccentric exercise and ischemia/reperfusion. Scand. J. Med. Sci. Sports, 20, 5, 748-756.

121. Stoffels, F., Lohöfener, F., Beisenhirtz, M., Lisdat, F., \& Büttemeyer, R. (2007). Concentration decrease of nitric oxide in the postischemic muscle is not only caused by the generation of $\mathrm{O}^{2-}$. Microsurgery, 27, 6, 565-568.

13. Hudyma, A.A., Kashchak, T.V., \& Shepitko, K.V. (2019). Antyoksydantno-prooksydantnyy ta tsytokinovyi balans u piznii period kombinovanoi travmy v eksperymenti [Antioxidant-prooxidant and cytokine balance in the late period of combined trauma in the experiment]. Svit medytsyny ta biolohii - World of Medicine and Biology, 1 (67), 4247 [in Ukrainian].

\section{ОСОБЕННОСТИ НАРУШЕНИЙ ПОКАЗАТЕЛЕЙ ЭНЗИМНОГО ЗВЕНА АНТИОКСИДАНТНОЙ СИСТЕМЫ В ЛЕГКИХ КРЫС ПОСЛЕ ОСТРОЙ КРОВОПОТЕРИ, ОСЛОЖНЕННОЙ ИШЕМИЕЙ-РЕПЕРФУЗИЕЙ КОНЕЧНОСТИ}

๑В. В. Стахив, А. А. Гудыма

Тернопольский национальный медицинский университет имени И. Я. Горбачевского МОз Украины

РЕЗЮМЕ. ОДним из ключевых патогенных механизмов массивной наружной кровопотери из конечностей является активация процессов липидной пероксидации, что обусловлено, с одной стороны, развитием гипоксии, с другой - истощением антиоксидантной защиты. Применение в этих условиях кровоостанавливающего жгута сопровождается ишемически-реперфузионным повреждением конечности, что осложняет течение острой кровопотери. На сегодня недостаточно данных об особенностях нарушений антиоксидантной защиты в легких, которые принадлежат к ключевым органам-мишеням острой кровопотери и ишемически-реперфузионного синдрома.

Цель - выяснить особенности нарушений показателей энзимного звена антиоксидантной системы в легких крыс после острой кровопотери, осложненной ишемией-реперфузией конечности. 
Огляди літератури, оригінальні дослідження, погляд на проблему, випадок з практики, короткі повідомлення

Материал и методы. Исследование проведено на 156 белых нелинейных крысах-самцах массой $200-220$ г. Все эксперименты выполнены под тиопентал-натриевым наркозом. У животных моделировали ишемию-реперфузию конечности, острую кровопотерю и сочетали эти повреждения. Через 1 и 2 часа, а также через 1, 7 и 14 суток в гомогенатах легких подопытных животных определяли активность супероксиддисмутазы и каталазы.

Результаты. В условиях моделирования только ишемии-реперфузии конечности активность СОД и каталазы в гомогенате легких росла с максимумом через 2 часа эксперимента и нормализацией показателей до 14 суток. В условиях острой кровопотери показатели росли во все сроки наблюдения с максимумом через 1 сутки эксперимента. Дополнительная ишемия-реперфузия конечности на фоне острой кровопотери в легких способствует истощению СОД и каталазы, активность которых через 1, 7 и 14 суток становится существенно менше, по сравнению с животным опытной группы, в которой моделировали только кровопотерю.

Выводы. Осложнения острой кровопотери ишемией-реперфузией конечности способствует большему истощению в легких ферментативного звена антиоксидантной защиты через 1, 7 и 14 суток эксперимента, что проявляется существенным снижением активности СОД и каталазы в легких по сравнению с животными, которым моделировали только острую кровопотерю.

КЛючЕВЫЕ СЛОВА: острая кровопотеря; ишемия-реперфузия конечности; супероксиддисмутаза; каталаза; легкие.

\section{PECULIARITIES OF DISORDERS OF ENZYME LINKS OF ANTIOXIDANT SYSTEM IN LUNGS OF RATS AFTER ACUTE BLOOD LOSS, COMPLICATED BY ISCHEMIA-REPERFUSION OF THE LIMB}

\section{Horbachevsky Ternopil National Medical University}

SUMMARY. One of the key pathogenic mechanisms of massive external blood loss from the extremities is the activation of lipid peroxidation, due on the one hand to the development of hypoxia, on the other - the depletion of antioxidant protection. The use of a tourniquet under these conditions is accompanied by ischemic-reperfusion injury of the limb, which complicates the course of acute blood loss. To date, there is insufficient data on the features of antioxidant defense disorders in the lungs, which belong to the key target organs of acute blood loss and ischemic-reperfusion syndrome.

The aim - to determine the features of disorders of the enzyme link of the antioxidant system in the lungs of rats after acute blood loss complicated by ischemia-reperfusion of the limb.

Material and Methods. The study was performed on 156 white nonlinear male rats weighing 200-220 g. All experiments were performed under thiopental-sodium anesthesia. In animals, limb ischemia-reperfusion and acute blood loss were simulated and these lesions were combined. After 1 and 2 hours, as well as after 1, 7 and 14 days in the lung homogenates of the experimental animals was determined by the activity of superoxide dismutase and catalase.

Results and Discussion. Under the conditions of modeling only ischemia-reperfusion of the limb, the activity of SOD and catalase in the lung homogenate increased with a maximum after $2 \mathrm{~h}$ of the experiment and normalization of values up to 14 days. Under conditions of acute blood loss, the indicators increased in all terms of observation with a maximum after 1 day of the experiment. Additional ischemia-reperfusion of the limb on the background of acute blood loss in the lungs contributes to the depletion of SOD and catalase, the activity of which after 1, 7 and 14 days becomes significantly less than in the animal experimental group, which simulated only blood loss.

Conclusions. Complications of acute blood loss by ischemia-reperfusion of the limb contribute to greater depletion in the lungs of the enzymatic link of antioxidant protection after 1, 7 and 14 days of the experiment, showing a significant decrease in SOD and catalase activity in the lungs compared to animals simulated only acute blood loss.

KEY WORDS: acute blood loss; ischemia-reperfusion of the limb; superoxide dismutase; catalase; lungs. 